\title{
Periimplantation subprogram for morphogenesis - the evolutionary know-how of eutherians
}

\author{
Yu. V. Vagyn \\ The Institute of Molecular Biology and Genetics \\ 150 Zabolotny Str., Kyiv 03143, Ukraine \\ vagin@imbg.org.ua
}

The occurrence of periimplantation subprogram for morphogenesis in eutherians, as a specific evolutionary acquirement, typical for members of the infraclass involved, has been substantiated.

Keywords: eutherians, morphogenesis, evolution

Eutheria, generally regarded as the placental, belong to the most advanced mammalian infraclass [1]. Unlike Monotremata and Marsupialia, Eutheria are specific for a more advanced reproductive system, which allows them to occupy various ecological niches and to spread to different climatic zones. In the areas where Monotremata and Marsupialia tried competing Eutheria, usually, the preference was given to the representatives of the latter. Both the data of palaeontological researches and the data of ecologists, who observed the process of mammalian colonisation of Australian continent, testify to the mentioned fact [1].

Although the presence of placenta is considered to be a specific feature of higher mammals, placenta is also present in some Lacerta, Serpentes, and Marsupialia [1,3]. Yet in Eutheria only, the process of placenta formation is preceded by the period of periimplantation [3]. Periimplantation in mammalian female specimen is characterised by the series of morphological and physiological changes in uterus and embryo [3-6]. Complete information on these events is presented in the research data on murine rodents [3, 4].

(C)

YU. V. VAGYN, 2007
A number of methods, aimed at the investigation of events which condition the course of the periimplantation and its final stage - the implantation on molecular-genetic level were elaborated [7]. The application of these methods allowed obtaining the general representation of hereditary programmes and molecular ways of realisation of these programmes, associated with the aforementioned process.

As a result it has been revealed that, the events, connected with preparation and successful conclusion of periimplantation, are dependent significantly on the "dialogue" between the embryo and the uterus on the cell-molecular level [8-10]. This kind of "dialogue" is to initiate uterus susceptibility and the degree of embryo readiness to be implanted $[3,10,11]$. The period of susceptibility is limited in time $[3,4,10]$ and uterus environment is capable of maintaining blastocyst growth, attachment, and subsequent implantation [3, 12].

Ovarian steroids - progesterones and/or estrogens are considered to be the main factors determining uterus susceptibility. However, if the implantation in mice and rats depends on both hormones, then in mustelids, pigs, Guinea pigs, rabbits, and cricetids the mentioned process is ensured by progesterone only [3, $4,13,14]$. 
The most essential step forward in understanding the nature of factors, which control the period of periimplantation in mammals, was made in the investigations on rodents. The processes of activation and implantation of their blastocysts were shown to be initiated rapidly by a single injection of estrogen into the progesterone-charged uterus [3, 4].

Three phases of uterus susceptibility towards implantation can be distinguished: i) pre-receptive (uterus has not acquired susceptibility towards the implantation) ii) receptive (uterus is susceptible to implantation) iii) non-receptive (refractive) (uterus lost susceptibility to implantation) [4]. The temporary period, when the uterus is in the receptive phase, was called the implantation window [3].

It has been noted earlier that Eutheria are specific for the state of receptivity at the condition of uterus "communication" with the embryo [3,8-11]. The duration of this state is very limited [4].

It has been shown in $[3,4]$ that murine uterus is completely receptive on the fourth day of pregnancy and may be considered pre-receptive in the course of first three days of pregnancy or pseudo-pregnancy. At the same time murine uterus can be made receptive using small doses of oestrogen in 24-48 hours after uterus was charged with progesterone. The receptivity and, therefore, the effectiveness of implantation decrease gradually and on the sixth day the uterus becomes completely refractive. It has been determined that the state of openness-closeness of the "implantation window" in mice is determined by the levels of oestrogen concentration in a rather narrow range - at low oestrogen concentrations the "window" remains open for a long time, however, this "window" closes down dramatically at their increase. At the same time, high levels of oestrogen result in transition of the uterus to the non-receptive phase, determine non-specific expression of genes for this phase which occurs due to implantation [4].

Blastocyst, or to be more precise - its activity, is considered to be one more important factor, which controls the formation of "implantation window" [15].

Obviously, active and latent blastocysts differ molecularly and physiologically. Thus, receptor of epidermal growth factor - cyclooxygenase-2 (COX-2) - and histamine receptor type II are the factors, connected to the reaction of attachment and are expressed in re-acti- vated blastocysts, however, their expression decreases in latent ones [15-18]. On the contrary, cannabinoid receptor, bound with $\mathrm{G}$ protein, which is activated with the introduction of cannabinoids, as well as endocannabinoids, decreases its expression in active blastocysts and increases in the latent ones [19]. Generally, these data unveil the specificity of molecular mechanisms which control the activation of blastocyst and its quiescence.

The intimate dialogue between the blastocyst and the uterus during the implantation possesses some specificities of reciprocal epithelial-mesenchymal interactions and includes a series of evolutionary conservative signalling factors $[3,9,20]$. Many of these factors play the important role in the processes of implantation and spatial localisation of the embryo inside the uterus; in particular they include epidermal growth factors (EGF), growth factors of fibroblast, lipids, insulin-like growth factors, morphogenetic bone proteins (MBP), proteins, encoded by Indian hedgehog (Ihh) gene, as well as their receptors and antagonists [4, 21-23]. In the course of periimplantation period these factors are expressed in murine uterus in definite spatial and temporal sequence.

It was clarified that the reaction of blastocyst attachment is related to local (in uterus stroma) induction of genes, encoding MBP-2 and growth factor of fibroblasts-2 $[9,21]$. The same investigations revealed that beads, wetted with EGF-similar factor GSEGF or insulin growth factor, but not with any other proteins, induce some local reactions in the uterus, similar to those induced by blastocyst, namely, increased vascular penetration, decidualisation, and expression of MBK-2 and COG-2.

Also it has been shown that the preparation of the uterus for the implantation is specific for spatial and temporal expression of genes, encoding the components of Hedgehog(Hh)-signalling pathway [24-26]. The expression of these genes had been increasing in lumen epithelium and uterus glands from the $3^{\text {rd }}$ day of pregnancy and reached its peak on the $4^{\text {th }}$ day [27]. Transcription of Hh-signalling pathway genes in sprayed mice was induced exceptionally by progesterone [26]. At the same time the induction of the expression of the aforementioned genes in response to progesterone treatment in the uteri of mice, mutant to the pro- 
gesterone receptor gene, was observed to be at a significantly lower level. Ihh gene expression was detected in uteri of cricetids under the influence of the mentioned hormone [28].

It is most likely that progesterone regulates the expression of genes, encoding the components of Hh-signalling pathway, yet not only via its own nuclear receptor but also via the by-pass, avoiding the receptor [29].

Nowadays it is absolutely obvious that the signalling pathways, forming the network of dialogues between the embryo and the uterus, are the integral attribute of the implantation in all studied species of eutherians [3, 9, 21, $23,30]$. Specifically the integrins and their receptors trophinin-testin-bistin complex as well as the number of other cell surface molecules, participate in adhesive cascade, securing the connection of the blastocysts in the places of implantation [3, 20, 31, 32]. GSEGF factor, inhibiting leukaemia (LIF) and homeobox-containing transcriptional factors are known to play the important role in the process of implantation in many mammalian species $[4,9,10,17,20]$. They are supposed to form a single signalling pathway and merge with phospholipase-A2-COG-2 signalling pathway at the last stage, thereby providing the successful implantation [9].

In the recent years the idea of endocannabinoids as the key signalling link, providing synchronisation of embryonic development and perceptiveness of uterus has been formed [9, 19, 20, 30, 33, 34].

However, all participants of implantation signalling pathways as well as the specificities of their functioning have not been listed yet, i.e. whether they interact independently, simultaneously or whether they converge to common denominator, remains to be a mystery $[4,9]$.

Regardless of the fact that the mechanics and the architecture of the implantation in majority of eutherians vary [3], a series of issues identical for the aforementioned process may be singled out. Hence, the implantation takes place at the stage of blastocyst, which is specific for the "window" of uterus receptivity, reciprocal interaction between the blastocyst and the uterus, as well as the increase in vascular penetrability of the uterus in the place of blastocyst adjoining $[3,4]$. Therefore, recognition and analysis of the signalling pathways at the mentioned stages may bring to initiation of the unified implantation scheme [3], which is also testified by the research data of mustelids.
It has been revealed that mink LIF protein during the implantation is localised on the uterine bottom and neck [35]. Skunk uterus was specific for the increased concentration of mRNA of LIF $\beta$-receptor in the places of blastocyst implantation [36, 37].

These results allow authors to suppose that mustelid LIF controls the process of blastocyst implantation [35-37].

There are some data showing that during the implantation $\operatorname{Cog}-2$ gene is expressed in the places of attachment and invasion of trophoblast [38]. At the same time, the results obtained on skunks revealed that Cog-2 is expressed during the implantation in both uterus and blastocyst [39].

Thus, increased $\operatorname{Cog}-2$ expression in both minks and skunks is correlated in time with the inflow of plasma proteins into the uterus and the reaction of blastocyst attachment. According to the authors' opinion $[38,39]$ these facts confirm the fact that local production of prostaglandin in mustelids may be considered as the initial inductor of the processes, responsible for the preparation of uterus to implantation.

The investigation of the periimplantation process in skunks revealed significant enlargement of EGF receptors in blastocysts as well as increase in the number of its transcripts in the uterus, which correlate with the restoration of the embryonic development and occur at the moment of rapid increase in the mitotic activity rate of embryos [40].

Recently, reactivated blastocysts of minks were revealed to have the expression of EGF of fibroblasts-4 (FGF-4) as well as the expression of receptor FGF-2 (FGFR-2), detected in blastocysts only on the $5^{\text {th }}$ day after their reactivation [41]. At the same time it was revealed that internal cell mass of mink blastocyst expresses both FGF-4 and FGFR-2, and trophoblast expresses FGFR-2 only, which plays the important role in the periimplantational proliferation of embryonic components.

The investigation on the role of vascular endothelial growth factor (VEGF) and its receptors during the periimplantation process in minks was carried out. It was determined that in the course of the periimplantation period the females are specific for a significant increase in uterine expression of VEGF and its receptors, VEGF-1 and VEGF-2 [42]. This expres- 
sion is controlled by prostaglandins, COG-2 derivatives, which was also confirmed by the results of investigation, carried out on mice [43]. It was revealed that prostacyclin, COG-2 derivative of prostaglandin, is involved in the implantation in mice, and its effect is mediated by the proliferator of peroxisome-active receptor $\delta$ (PPAR $\delta$ ) [44].

The expression of COG-2 in minks is a transient event - it takes place during the attachment of trophoblast and invasion of blastocyst [38] at the same time it correlates with the increase of VEGF in the uteri [42]. The process of implantation in minks is accompanied by the expression in PPAR? endometrium [45].

Literature contains the data on the issue that not only uterus [38] but also some reactive mink embryos produce prostaglandins, $\mathrm{PGE}_{2}$ in particular $[45,46]$. The latter is the effective inducer of VEGF expression in various tissues [47], and its expression is observed in the uteri of mice in the course of implantation [44].

One more potential regulator of VEGF expression is PGJ, which activates VEGF in human macrophages via PPAG $\gamma$ [48]. PPAG $\gamma$ expression in minks is secured in trophoblast during the implantation of blastocyst [45]. It has to be remembered that VEGF acts by means of its tyrosine kinase receptors VEGF-1 and VEGF-2 [49]. In case of minks the rise in the levels of expression of VEGF receptors is also correlated with the implantation and is associated with the presence of reactivated embryos in the uterus [42].

One of the latest works presents the evidence of the fact that the important role in the vascularisation in minks, connected with the implantation of blastocysts is played by $\mathrm{PGE}_{2}$; at the same time $\mathrm{PGE}_{2}$ effects the mentioned process via its receptors EP2 and EP4 [46].

Stating on the mentioned above, currently known details on signalling pathways of implantation in mustelids [10] reveal some similarity with those of murine rodents [23].

Therefore, the results of the analysis performed allow concluding that periimplantation period is specific for active dialogue between the embryo and the uterus, which has to prepare the "participants" to be implanted. The information constituent of this dialogue is composed by the positive selection throughout the evolution of eutherians and is presented as special "hybrid" (embryonic and maternal) sub-programme, controlling the process of periimplantation.

The presence of such programme differentiates Eutheria from other mammalian specimen, i.e. Monotremata and Marsupialia. This sub-programme is to enable the informational support, directed at the coordination of morphogenetic processes, providing finally, the in-time implantation of blastocysts. Regardless of some specific differences in the content of this sub-programme, in all studied eutherians it is realised in the course of periimplantation by means of active embryo-uterus dialogue exclusively. At the same time, according to modern views, the number of expressed genes varies from several hundreds to more than a thousand of genes, which are the part of both mother's and embryo's genomes $[4,11,19,23,30]$. The expression of these genes is of clear-cut spatial and temporal sequence, the fluctuations from which may result in fatal consequences for the development of progeny in the mother's womb [3,4]. The developing progeny may be injured by the genetic disorders, causing the informational changes in the mentioned sub-programme.

Therefore, successful reproduction of eutherians is heavily dependent on the quality and timeliness of realisation of morphogenetic sub-programme, controlling the periimplantation. Thus the conclusion can be made - the effect of the stabilising positive selection in the process of periimplantation, established in the example of minks [50], is directed towards the protection and in some cases correction of the aforementioned sub-programme [51].

Ю. В. Вагин

Периимплантационная подпрограмма

морфогенеза - эволюционное know how плацентарных млекопитающих

Резюме

Обосновано наличие $y$ плачентарных млекопитающих периимплантационной подпрограммы морфогенеза как специфичческого эволюционного приобретения, характерного для представителей упомянутого инфракласса.

Ключевые слова: плацентарные млекопитающие, морфогенез, эволюиия. 


\section{REFERENCES}

1. Ромер А., Парсонс T. Анатомия позвоночных.-М.: Мир, 1992.-T.1.-357 c.

2. Симпсон Дж. Великолепная изоляция.-М.: Мир, 1983. $-256 \mathrm{c}$.

3. Carson D. D., Bagchi I., Dey S. K., Enders A. C., Fazleabas A. T., Lessey B. A., Yoshinaga K. Embryo implantation// Develop. Biol.-2000.-223.- P. 217-237.

4. Dey S. K., Lim H., Das S. K., Reese J., Paria B. C., Daikoku $T$., Wang $H$. Molecular cues to implantation // Endocrine Revs.-2004.-25.-P. 341-373.

5. Mead A. M. Hormonal control of implantation in some carnivores // Molecular and cellular aspects of periimplamtation processis.-New York: Springer, 1995.P. 48-65.

6. Lopes F. L., Desmarais J., Murphy B. D. Embryonic diapause and its regulation // Reprodution.-2004.-128.-P. 669-678.

7. Deb K., Reese J., Paria B. C. Methodologies to study implantation in mice // Methods. Mol. Med.-2006.-121.P. 1219-1234.

8. Paria B. C., Song H., Dey S. K. Implantation: molecular basis of embryo-uterine dialogue // J. Develop. Biol.-2001.-45.P. 597-605.

9. Paria B. C., Reese J., Das S. K., Dey S. K. Deciphering the cross-talk of implantation advances and challenges // Science.-2002.-296.-P. 2185-2188.

10. Bordigon V., Lopes F. L., Murphy B. D., Desmarais J. Diapause, implantation in the mink: a critical role for embryonic signaling // Scientifur.-2004.-28.-P. 211-217.

11. Tranguch S., Daikoku T., Guo Y., Wang H., Dey S. K. Molecular complexity in establishing uterine receptivity and implantation // Cell Mol. Life Sci.-2005.-62.-P. 1964-1973.

12. Dey $S . K$. Implantation // Reproductive endocrinology, surgery and technology.-New York: Lippincott-Raven, 1996.-P. 421-434

13. Tranguch S., Smith D. F., Dey S. K. Progesterone receptor requires a co-chaperone for signaling in uterine biology and implantation // Reprod. Biomed. Online.-2006.-13.P. 651-660.

14. Zhang Q.,Paria B. C. Importance of uterine cell death, renewal, and their hormonal regulation in hamsters that show progesterone-dependent implantation // Endocrinology.2006.-147.-P. 2215-2227.

15. Paria B. C., Huet H., Dey $S$. K. Blastocyst's state of activity determines the "window» of implantation in the receptive mouse uterus // Proc. Nat. Acad. Sci. USA.-1993.-90.P. 10159-10162.

16. Paria B. C., Das S. K., Andrews G. K., Dey S. K. Expression of the epidermal growth factor receptor gene is regulated in mouse blastocysts during delayed implantation // Proc. Nat. Acad. Sci. USA.-1993.-90.-P. 55-59.

17. Lim H., Das S. K., Dey S. K. erbB genes in the mouse uterus: cell-specific signaling by epidermal growth factor (EGF) family of growth factors during implantation // Develop. Biol.-1998.-204.-P. 97-110.

18. Zhao X., Ma W., Das S. K., Dey S. K., Paria B. C. Blastocyst $\mathrm{H}(2)$ receptor is the target for uterine histamine in implantation in the mouse // Development.-2000.-127.P. 2643-2651.

19. Paria B. C., Song H., Wang X., Schmid P. C., Krebsbach R. J., Schmid H. H., Bonner T. I., Zimmer A., Dey S. K.
Dysregulated cannabinoid signaling disrupts uterine receptivity for embryo implantation // J. Biol. Chem.-2001.-276.-P. 20523-20528.

20. Lim H., Song H., Paria B. C., Reese J., Das S. K., Dey S. K. Molecules in blastocyst implantation: uterine and embryonic perspectives // Vitam. Horm.-2002.-64.-P. 43-76.

21. Paria B. C., Ma W., Tan J., Raja S., Das S. K., Dey S. K., Hogan B. L. Cellular and molecular responses of the uterus to embryo implantation can be elicited by locally applied growth factors // Proc. Nat. Acad. Sci. USA.-2001.-98.P. 1047-1052.

22. Wang H., Dey S. K. Lipid signaling in embryo implantation // Prostaglandins Other Lipid Mediat.-2005.-77.-P. 84-102.

23. Wang H., Dey S. K. Roadmap to embryo implantation: clues from mouse models // Nat. Rev. Genet.-2006.-7.-P. 18-199.

24. Ingham P. W., McMahon A. P. Hedgehog signaling in animal development: paradigms and principles // Genes Develop.-2001.-15.-P. 3059-3087.

25. Johnson R. L., Scott M. P. New players and puzzles in the hedgehog signaling pathway // Curr. Opin. Genet. Develop.-1998.-8.-P. 450-456.

26. McMahon A. P. More surprises in the hedgehog signaling pathway // Cell.-2000.-100.-P. 185-188.

27. Matsumoto H., Zhao X., Das S. K., Hogan B. L., Dey S. K. Indian hedgehog as a progesterone-responsive factor mediating epithelial-mesenchymal interactions in the mouse uterus // Develop. Biol.-2002.-245.-P. 280-290.

28. Khatua A., Wang X., Ding T., Zhang Q., Reese J., DeMayo F. J., Paria B. C. Indian hedgehod, but not histidine decarboxylase or amphiregulin, is a prodesterone-regulated uterine gene in hamsters // Endocrinology.-2006.-147.P. 4079-4092.

29. Takamoto N., Zhao B., Tsai S. Y., DeMayo F. J. Identification of Indian hedgehog as a progesterone-responsive gene in the murine uterus // Mol. Endocrinol.-2002.-16.-P. 2338-2348.

30. Wang H., Xie H., Sun X., Kingsley P. J., Marnett L. J., Cravatt B. F., Dey $S$. $K$. Differential regulation of endocannabinoid synthesis and degradation in the uterus during embryo implantation // Prostaglandins Other Lipid Mediat.-2007.-83.-P. 62-74.

31. Norwitz E. R., Schust D. J., Fisher S. J. Implantation and the survival of early pregnancy // New Engl. J. Med.2001.-345.-P. 1400-1408.

32. Kimber S. J., Spanswick C. Blastocyst implantation: the adhesion cascade // Semin. Cell Develop. Biol.-2000.-11.P. 77-92.

33. Wang H., Xie H., Dey S. K. Endocannabinoid signaling directs periimplantation events // AAPS J.-2006.-8.P. 425-432.

34. Wang H., Dey S. K., Maccarone M. Jekyll and hyde: two faces of cannabinoid signaling in male and female fertility // Endocrinol. Revs.-2006.-27.-P. 427-480.

35. Song J. H., Houde A., Murphy B. D. Cloning of leukemia inhibitory factor (LIF) and its expression in the uterus during embryonic diapause and implantation in the mink (Mustela vison) // Mol. Reprod. and Develop.-1998.-51.-P. 13-21.

36. Hirzel D. J., Wang J., Das S. K., Dey S. K., Mead R. A. Changes in uterine expression of leukemia inhibitoryfactor during pregnancy in the Western spotted skunk // Biol. Reprod.-1999.-60.-P. 484-492.

37. Passavant C., Zhao X., Das S. K., Dey S. K., Mead A. M. Changes in uterine expression of leukaemia inhibitory factor receptor gene during pregnancy and its up-regulation by 
prolactin in the western spotted skunk // Biol. Reprod.-2000.-63.-P. 301-307.

38. Song J. H., Sirois J., Houde A., Murphy B. D. Cloning, developmental expression, and immunohistochemistry of cyclooxygenase 2 in the endometrium during embryo implantation and gestation in the mink (Mustela vison) // Endocrinology.-1998.-139.-P. 3629-3636.

39. Das S. K., Wang J., Dey S. K., Mead R. A. Spatiotemporal expression of cyclooxygenase 1 and cyclooxygenase 2 during delayed implantation and the periimplantation period in the Western spotted skunk // Biol. Reprod.-1999.-60.P. 893-899.

40. Paria B. C., Das S. K., Mead R. A., Dey S. K. Expression of epidermal growth factor receptor in the preimplantation uterus and blastocyst of the western spotted skunk // Biol. Reprod.-1994.-51.-P. 205-213.

41. Desmairs J. A., Bordignon V., Lopes F. L., Smith L. C., Murphy B. D. The escape of the mink embryo from obligate diapause // Biol. Reprod.-2004.-70.-P. 662-670.

42. Lopes F. L., Desmairs J. A., Gevry N. Y., Ledox S., Murphy B. $D$. Expression of vascular endothelial growth factor isoforms and receptors Flt-1 and KDR during the peri-implantation period in the Mink, Mustela vison // Biol. Reprod.-2003.-68.-P. 1926-1933.

43. Lim H., Paria B. C., Das S. K., Dinchuk J. E., Langenbach R., Trzaskos J. M., Dey $S$. K. Multiple female reproductive failures in cyclo-oxygenase 2-deficient mice // Cell.-1997.-91.-P. 197-208.

44. Lim H., Gupta R. A., Ma W. G., Paria B. C., Moller D. E., Morrow J. D., DuBois R. N., Trzaskos J. M., Dey S. K. Cyclo-oxygenase-2-derived prostacyclin mediates embryo implantation in the mouse via PPAR $\delta$ // Genes Develop.-1999.-13.-P. 1561-1574.

45. Desmarais J., Bennett R. D., Gevry N., Murphy B. D. The role of peroxisome proliferator-activated receptor delta in the process of implantation in the mink Mustela vison // Biol. Reprod.-2002.-66 (suppl. 1).-P. 123.

46. Lopes F. L., Desmarais J., Ledoux S., Gervy N. Y., Lefevre P., Murphy B. D. Transcriptional regulation of uterine vascular endothelial growth factor during early gestation in a carnivore model, Mustela vison // J. Biol. Chem.2006.-281.-P. 24602-24611.

47. Bamba H., Ota S., Kato A., Kawamoto C., Fujiwara K. Prostaglandins up-regulate vascular endothelial growth factor production through distinct pathways in differentiated U937 cells // Biochem. and Biophys. Res. Communs.2000.-273.-P. 485-491.

48. Tarrade A., Schoonjans K., Guibourdenche J., Bidart J. M., Vidaud M., Auwerx J., Rochette-Egly C., Evain-Brion D. PPAR gamma/RXR alpha heterodimers are involved in human $\mathrm{CG}$ beta synthesis and human trophoblast differentiation // Endocrinology.-2001.-142.-P. 4504-4514.

49. Matsumoto T., Claesson-Welsh L. VEGF receptor signal transduction // Sci. STKE.-2001.-P. 21.

50. Вагин Ю. В. Доказательства действия дарвиновского отбора на пренатальной стадии онтогенеза // Физиология и биохимия культурных растений.-2006.-38, № 2.C. $134-143$.

51. Вагин Ю. В. Положительный отбор генов-модификаторов - путь фиксации наследственных изменений в популяциях // Биополимеры и клетка.-2007.-23, № 3.C. $255-259$.

УДК $577.21+575.857$

Надійшла до редакції 05.06.07 